\title{
EVALUASI PELAKSANAAN PENDIDIKAN KELUARGA PADA KAMPUNG KB DI KABUPATEN/KOTA PROVINSI SUMATRA BARAT
}

\author{
Remiswal $^{\left.1^{*}\right)}$, Duski Samad ${ }^{2}$, Arham Junaidi Firman $^{3}$ \\ ${ }^{1}$ Program Studi Tadris IPS, Fakultas Tarbiyah dan Keguruan, \\ UIN Imam Bonjol, Padang 25176, Indonesia \\ ${ }^{2}$ Program Studi Pendidikan Agama Islam, Fakultas Tarbiyah dan Keguruan, \\ UIN Imam Bonjol, Padang 25176, Indonesia \\ ${ }^{3}$ Program Studi Pendidikan Agama Islam, Fakultas IImu Tarbiyah dan Keguruan, \\ UIN Sunan Kalijaga, Yogyakarta 55281, Indonesia
}

${ }^{*}$ E-mail: remiswal@uinib.ac.id

\begin{abstract}
Abstrak
Pelaksanaan pendidikan keluarga pada Kampung KB di Kabupaten/Kota Provinsi Sumatra Barat untuk mengatasi masalah kependudukan belum pernah dievaluasi sejak dicanangkan tahun 2016. Penelitian ini bertujuan untuk mengevaluasi pelaksanaan pendidikan keluarga pada Kampung KB di Kabupaten/Kota Provinsi Sumatra Barat. Penelitian ini menggunakan desain studi evaluatif dengan pendekatan kualitatif dan kuantitatif di Kota Padang, Kota Padang Panjang, Kabupaten Pasaman Barat, dan Kota Solok yang dipilih secara purposif pada tahun 2018 pada periode bulan Juli hingga Oktober. Sumber data dalam penelitian ini meliputi OPD-KB Kab/Kota, PLKB, Ketua, Kader, dan seksi Kampung KB, Tokoh Agama, Tokoh Masyarakat, Ketua PKK dan 50 PUS yang ditentukan secara systematic random sampling pada masing-masing Kampung KB. Analisis data dilakukan secara deskriptif. Hasil penelitian: pertama, pembinaan dan penggerakkan pendidikan keluarga oleh pengelola program Kampung KB masih belum memperlihatkan posisi sentral dalam meningkatkan kesadaran dan kemampuan teknis keluarga. Kedua, sarana dan prasarana pendidikan keluarga pada setiap Kampung KB masih belum terealisasi dengan semestinya. Ketiga, langkah dan upaya strategis dari Pemerintah belum terlihat untuk pencapaian indikator program Kampung KB dalam pelaksanaan pendidikan keluarga. Keempat, PUS memiliki pengetahuan dan partisipasi pada setiap kegiatan dan program yang diselenggarakan oleh Kampung KB. Hasil penelitian ini merekomendasikan pentingnya komitmen dan sinergi pemerintah, pengelola, masyarakat, dan stakeholder dalam menyukseskan pendidikan keluarga pada Kampung KB.
\end{abstract}

Kata kunci: kampung KB, kependudukan, pasangan usia subur, pendidikan keluarga, studi evaluasi

\section{Evaluation of the Implementation of Family Education on Family Planning Village in Regency/City of West Sumatra Province}

\begin{abstract}
The implementation of family education on Family Planning Village in Regency/City of West Sumatra Province to overcome population problems has not been evaluated since it was launched in 2016. This research was aimed to evaluate the implementation of family education on Family Planning Village in Regency/City of West Sumatra Province. This research used an evaluative study design with qualitative and quantitative approaches in Padang City, Padang Panjang City, West Pasaman Regency, and Solok City which were selected purposively in 2018 in the period of July to October. The data sources in this study include Regency/City Family Planning-Regional Device Organization, Family Planning Field Extension, Chairman, Cadres, and Family Planning Village section, Religious Leaders, Community Leaders, Heads of Family Welfare Empowerment and 50 Couples of Childbearing Age determined through a systematic random sampling in each Family Planning Village. Analyses were done descriptively. The results showed; first, the development and mobilization of family education by the manager of the Family Planning Village program still did not show a central position in raising awareness and technical capabilities of the family. Second, the facilities and infrastructure of family education in each Family Planning Village were still not realized properly. Third, the strategic steps and efforts of the Government had not been seen to achieve the indicators of the Family Planning Village program in the implementation of family education. Fourth, Couples of Childbearing Age had knowledge and participated in every activity and program organized by the Family Planning Village. The results of this study suggest the importance of commitment and synergy of governments, managers, communities and stakeholders in establishing a good family education in Family Planning Village.
\end{abstract}

Keywords: couples of childbearing age, evaluation study, family education, family planning village, population 


\section{PENDAHULUAN}

Kampung Keluarga Berencana (KB) merupakan miniatur penyelenggaraan program $\mathrm{KB}$ yang integral dan komprehensif di setiap lini lapangan, seperti tingkat desa, tingkat kelurahan, tingkat dusun atau tingkat RW. Kampung KB menjadi konsep integral program KB bersama program pembangunan lainnya seperti ekonomi dan pendidikan (Mardiyono, 2017). Eksistensi Kampung KB didasarkan kepada "UU Nomor 52 Tahun 2009" dan lampiran "UU Nomor 23 Tahun 2014" pada huruf $\mathrm{N}$. Lebih lanjut, BKKBN mendapatkan amanah untuk ambil bagian dalam menyukseskan agenda yang menjadi prioritas pemerintah nomor lima pada tahun 2015 hingga 2019. Hal ini kemudian dituangkan ke dalam "Rencana Pembangunan Jangka Menengah Nasional" dan "Rencana Strategis" dari BKKBN dengan menguatkan pelaksanaan pendidikan keluarga pada lini lapangan melalui Kampung KB (BKKBN, 2016).

Kampung KB sebagai tempat pelaksanaan pendidikan keluarga dibentuk untuk meminimalisir dan mengatasi masalah kependudukan di Indonesia karena masih diwarnai oleh banyaknya jumlah penduduk dengan angka kelahiran dan pertumbuhan yang tinggi sehingga belum bisa diatasi sampai sekarang (Rahmeina, 2018). Secara umum, ada tiga macam masalah kependudukan yang terdapat di Indonesia khususnya Sumatra Barat, yaitu persebaran tidak merata tiap wilayah, kualitas, dan komposisi usia remaja (BKKBN, 2016).

Data BPS (2018) Provinsi Sumatra Barat menunjukkan bahwa jumlah penduduk dengan angka buta huruf sebesar 1,29 persen, komposisi usia remaja (15-24 tahun) berjumlah 922.703 jiwa, dan persebaran penduduk masih belum tersebar secara merata, seperti penduduk Kota Padang berjumlah 927.011 jiwa dan Kepulauan Mentawai berjumlah 88.692 jiwa. Sementara itu, data BKKBN (2017b) menunjukkan bahwa terdapat 175 Kampung KB sebagai tempat pelaksanaan pendidikan keluarga di Sumatra Barat untuk mengatasi masalah tersebut.

Pembentukan Kampung KB sebagai tempat pelaksanaan pendidikan keluarga untuk mengatasi masalah-masalah kependudukan merupakan bentuk pelaksanaan amanah yang diemban oleh pemerintah sebagaimana terdapat dalam Q.S. Al-Mu'minun ayat 8 (Departemen Agama, 2008). Keberhasilan dan kesuksesan Kampung KB dalam melaksanakan pendidikan keluarga untuk mengatasi masalah kependudukan dipengaruhi oleh komitmen pemerintah, pengelola dan peran aktif dari masyarakat khususnya keluarga (Prasetyo \& Anggaunitakiranantika, 2020). Oleh karena itu, partisipasi setiap keluarga pada Kampung KB dalam pelaksanaan pendidikan keluarga menempati posisi urgen untuk meminimalisir dan mengatasi masalah kependudukan. Kampung KB sebagai tempat pelaksanaan pendidikan keluarga telah dicanangkan sejak tahun 2016 di masing-masing Kabupaten/Kota Provinsi Sumatra Barat, namun belum pernah dilakukan evaluasi hingga saat ini. Arikunto dan Jabar (2009) menyatakan bahwa evaluasi program dilaksanakan untuk mendapatkan informasi terkait tercapainya tujuan suatu program melalui terlaksananya berbagai kegiatan. Lebih lanjut, Roswati (2008) menjelaskan bahwa salah satu manfaat yang dapat diperoleh dengan melaksanakan evaluasi program ialah mengetahui keberlanjutan (sustainability) program pada masa yang akan datang. Masalah tersebut menjadi daya tarik bagi peneliti untuk diangkat menjadi penelitian dengan fokus "Studi evaluasi pelaksanaan pendidikan keluarga pada Kampung KB di Kabupaten/Kota Provinsi Sumatra Barat."

Penelitian mengenai Kampung KB sudah banyak diteliti di Indonesia, diantaranya penelitian yang mengaitkan Kampung KB dengan efektivitas pelatihan Kampung KB (Angisna, 2018), dampaknya terhadap keluarga miskin (Restiyani \& Yasa, 2019), pemberdayaan masyarakat (Aji \& Yudianto, 2020), peningkatan program Kependudukan Keluarga Berencana Pembangunan Keluarga (KKBPK) (Mardiyono, 2017), dan kesejahteraan masyarakat (HM \& Indrawadi, 2019). Kajian lain juga menganalisis Kampung KB dari sisi faktor yang memengaruhi keberhasilannya (Sari et al., 2018), persepsi masyarakat (Alpionita, Arifin, \& Harahap, 2020; Setiawati, 2017; Wulandari, 2008), partisipasi masyarakat (Wiwiek \& Utami, 2020), implementasi (Anggraeni, Afifuddin, \& Suyeno, 2020; Bachtiyar \& Wibawani, 2018; Istiadi \& Rosdiana, 2012; Normajatun, Malawat, \& Fibriyanita, 2018; Nurjannah \& Susanti, 2018; Yunas \& Nailufar, 2019), identifikasi kegiatan (Syahnur, Diantimala, \& Ilham, 2019), koordinasi pengembangan (Regina, Rusli, \& Candradewini, 2020), dan efektivitas program (Widodo \& Anam, 2019; Zuhriyah, Indarjo, \& Raharjo, 2017). Beberapa penelitian terdahulu menunjukkan penemuan mengenai evaluasi Kampung KB (Handayani, Najib, Ardini, \& Yulianti, 2020; Mardani, Winaya, \& Purnamaningsih, 2020; Rianto, Nengsih, \& Setyadiharja, 2019). 
Selain itu, penelitian-penelitian terdahulu mengenai evaluasi Kampung KB (Handayani et al., 2020; Mardani et al., 2020; Rianto et al., 2019) dilakukan hanya terbatas pada evaluasi Kampung KB dan tidak memberikan spesifikasi mengenai pelaksanaan pendidikan keluarga seperti yang dilakukan dalam penelitian ini. Selama ini, belum ada spesifikasi penelitian mengenai evauasi pelaksanaan pendidikan keluarga pada Kampung KB sehingga penelitian ini sangat perlu untuk dilakukan terutama untuk mendapatkan gambaran tentang eksistensi Kampung KB yang telah dicanangkan sejak tahun 2016 dalam mengatasi masalah kependudukan. Penelitian ini bertujuan untuk mengevaluasi pelaksanaan pendidikan keluarga pada Kampung KB di Kabupaten/Kota Provinsi Sumatra Barat.

\section{METODE}

Penelitian ini menggunakan desain studi evaluatif di Kota Padang (Kampung KB Bangau Putih), Kota Padang Panjang (Kampung KB Kubu Gadang), Kabupaten Pasaman Barat (Kampung KB Jorong Pondok), dan Kota Solok (Kampung KB Payo Sejahtera) yang dipilih secara purposif dengan pertimbangan keterwakilan wilayah tahun 2018 pada periode bulan Juli hingga Oktober. Selanjutnya, penelitian ini menggunakan pendekatan kualitatif dan kuantitatif untuk mengumpulkan data. Pendekatan kualitalif bertujuan untuk mendapatkan informasi mendalam mengenai evaluasi pelaksanaan pendidikan keluarga pada Kampung KB yang melibatkan berbagai lintas sektor, pemerintah daerah, TOGA/TOMA, pengelola Kampung KB serta partisipasi masyarakat. Pengumpulan data dengan pendekatan kualitatif secara keseluruhan dilakukan melalui observasi, dokumentasi, dan wawancara mendalam dengan sumber data, yaitu OPD-KB Kab/Kota, PLKB, Ketua, Kader, dan seksi Kampung KB, Tokoh Agama, Tokoh Masyarakat, serta Ketua PKK. Selanjutnya, analisis data kualitatif dilakukan secara deskriptif berdasarkan model Miles dan Huberman dengan tahap reduksi, display, dan verifikasi data (Miles, Huberman, \& Saldana, 2014).

Sementara itu, pendekatan kuantitatif dilakukan dengan menggunakan kuesioner terstruktur mengacu pada Kusumah dan Dwitagama (2011) untuk memperoleh gambaran pengetahuan dan partisipasi masyarakat dalam kegiatan dan program pendidikan keluarga pada Kampung KB. Responden dengan pengumpulan data kuantitatif adalah Pasangan Usia Subur (PUS) yang dipilih dengan melakukan listing di wilayah Kampung KB, kemudian dilakukan random secara systematic random sampling (SRS) sebanyak 50 PUS pada masing-masing Kampung KB. Selain itu, responden yang memiliki anggota keluarga seperti anak balita, anak remaja, dan orang tua yang tinggal bersama responden ataupun yang tinggal di wilayah sasaran Kampung KB juga ditanyakan terkait pelayanan dan partisipasi di Kampung KB untuk mencari tingkat partisipasi PUS dan anggota keluarga yang mengikuti kegiatan dan program pendidikan keluarga di Kampung KB.

Pasangan Usia Subur ialah pasangan suami istri yang terikat melalui pernikahan yang sah dan istrinya berusia 15 sampai dengan 49 tahun (Pratiwi, 2019). Pengetahuan PUS adalah informasi yang dimiliki dan diketahui tentang kegiatan dan program pendidikan keluarga. Sementara itu, partisipasi PUS merupakan keikutsertaan dalam setiap kegiatan dan program pendidikan keluarga. Pengetahuan dan partisipasi PUS dalam penelitian ini meliputi kegiatan dan program pendidikan keluarga pada Kampung KB, seperti keluarga berencana, PKB, KIE individu, KIE kelompok, pembangunan keluarga, dan kegiatan pengurus KB (BKKBN, 2017a). Variabel pengetahuan dan partisipasi PUS diukur dengan skala Likert. Ada empat rentang pilihan untuk jawaban dari angka 1-4 (1=Tidak Baik, 2=Kurang Baik, 3=Baik, 4=Sangat Baik). Hasil uji reliabilitas menunjukkan kuesioner pengetahuan dan partisipasi PUS memiliki Cronbach's alpha dengan nilai 0,677. Pada penelitian ini, data PUS tergolong kepada data ordinal berdasarkan level pengukuran (Sugiyono, 2013). Data dianalisis secara statistik deskriptif melalui aplikasi SPSS (V.25.0). Analisis yang dilakukan terkait frekuensi (jumlah) dan proporsi (persentase) untuk mendapatkan gambaran pengetahuan dan partisipasi PUS dalam kegiatan dan program pendidikan keluarga pada Kampung KB. Selanjutnya, hasil analisis statistik deskriptif disajikan dan diolah dalam bentuk tabel untuk mempermudah melakukan interpretasi data.

\section{HASIL}

\section{Pembinaan dan Penggerakkan Pendidikan Keluarga oleh Pengelola Program Kampung KB}

Hasil penelitian menunjukkan bahwa minimnya kegiatan pendidikan keluarga yang dilakukan tidak lepas dari minimnya anggaran dana dan perhatian yang kurang responsif dari organisasi perangkat daerah (OPD) lintas sektor terhadap 
Kampung KB setelah pencanangan. Fakta di lapangan menunjukkan bahwa setelah pencanangan, Kampung KB tidak dibimbing dan diarahkan dalam membentuk dan melaksanakan setiap kegiatan yang berhubungan dengan KKBPK sebagai bentuk pendidikan keluarga. Responden PLKB di Kampung KB Bangau Putih melaksanakan tugas dan fungsinya dengan melakukan kegiatan-kegiatan pembinaan sebagai bentuk pendidikan keluarga. Namun, pelaksaan kegiatan tersebut belum didukung secara optimal oleh dukungan dana (APBN, APBD, $A D D, \quad C S R$, luran Masyarakat), dan menutupinya dengan dana lain untuk biaya operasional Kampung KB, seperti iuran dari Kader BKR dan Kader KB.

Responden PLKB di Kampung KB Kubu Gadang melaksanakan tugas dan fungsinya dengan memfasilitasi kegiatan-kegiatan pendidikan keluarga. Sementara itu, responden PLKB di Kampung KB Jorong Pondok melaksanakan tugas dan fungsinya dengan melakukan pembinaan Kader dan mencari sektor KB. Sementara itu, responden PLKB di Kampung KB Payo Sejahtera melaksanakan tugas dan fungsinya dengan memberikan sosialisasi dan fasilitasi terhadap kegiatankegiatan yang diadakan. Akan tetapi, dalam pelaksanaan kegiatan-kegiatan pendidikan keluarga pada Kampung KB Kubu Gadang, Kampung KB Jorong Pondok, dan Kampung KB Payo Sejahtera belum didukung oleh dukungan dana (APBN, APBD, ADD, CSR, luran Masyarakat) yang masih belum dianggarkan, dan tidak ada usaha yang dilakukan untuk memperoleh dukungan dana sebagai biaya operasional kegiatan pendidikan keluarga di Kampung KB.

Responden Kader Kampung KB Bangau Putih menjelaskan bahwa terkait dengan kegiatan Kampung KB, dia telah "lebih dari satu kali mengikuti kegiatan sosialisasi sebelum dan sesudah pembentukan Kampung KB oleh BKKBN Provinsi, OPD KB Kab/Kota yang dihadiri oleh masyarakat Kampung KB dengan materi sosialisasi konsep Kampung KB dan indikator keberhasilannya, rencana program dan kegiatan, AJK bulanan dan mingguan, alur penganggaran, format evaluasi dan pelaporan serta koordinasi lintas sektor." Hal ini diperkuat oleh pernyataan responden Kader Kampung KB Kubu Gadang, Kader Kampung KB Jorong Pondok, dan Kader Kampung KB Payo Sejahtera bahwa dia telah "lebih dari satu kali mengikuti kegiatan sosialisasi sebelum pembentukan Kampung KB oleh BKKBN Provinsi, OPD KB Kab/Kota yang dihadiri oleh perwakilan Kab/Kota se-Sumatra Barat dengan materi sosialisasi konsep Kampung KB dan indikator keberhasilannya, rencana program dan kegiatan, AJK bulanan dan mingguan, alur penganggaran, format evaluasi dan pelaporan serta koordinasi lintas sektor."

Berdasarkan hal itu, bentuk kegiatan pendidikan keluarga yang dilakukan kader Kampung KB Bangau Putih adalah melakukan pendataan lansia dan menjalin kerja sama masyarakat dengan BKKBN dalam kegiatan PKK, Menjahit, KIE melalui arisan dan kunjungan ke rumah-rumah sebulan sekali dengan anggota poktan yang aktif \pm 20 orang, tetapi kegiatan yang dilakukan ini tidak ada bedanya sebelum dan sesudah pembentukan Kampung KB. Selain itu, pertemuan rutin POKJA Kampung KB Bangau Putih dilaksanakan di UPT KB yang dihadiri oleh PLKB, Pengurus, dan Kader dengan materi sosialisasi tentang alat kontrasepsi. Sementara itu, sarasehan tingkat RT dilaksanakan di PKBM Farila IImi yang dihadiri oleh Kader, RT/RW, masyarakat. dan PLKB dengan materi gotong-royong sekali dalam seminggu.

Bentuk kegiatan pendidikan keluarga yang dilakukan kader Kampung KB Kubu Gadang adalah melakukan pembinaan Generasi Berencana (GenRe) dan berusaha mengatasi angka melek huruf dengan adanya taman bacaan di Kampung KB Kubu Gadang. Sementara itu, bentuk kegiatan pendidikan keluarga yang dilakukan kader Kampung KB Jorong Pondok adalah melakukan pembinaan terkait KKBPK kepada masyarakat dan berusaha untuk mengurangi serta mengatasi masalah melek huruf melalui taman bacaan di Kampung KB Jorong Pondok. Bentuk kegiatan yang dilakukan kader Kampung KB Payo Sejahtera adalah melaksanakan berbagai kegiatan.

Substansi materi yang disampaikan kepada anggota POKTAN pada Kampung KB Bangau Putih, Kampung KB Kubu Gadang, Kampung KB Jorong Pondok, dan Kampung KB Payo Sejahtera adalah pelayanan KB dan kegiatankegiatan yang bersangkutan dengan TRIBINA. Bentuk kegiatan KIE yang dilakukan adalah kegiatan Posyandu dengan media lembar balik dan pertemuan bulanan forum $\mathrm{KB} / \mathrm{KS}$ yang dilaksanakan 1 kali dalam sebulan setelah kegiatan Posyandu. Selama melaksanakan kegiatan tersebut, hanya 1 orang anggota POKTAN yang aktif, yaitu sub PPKBD. Setelah berjalan 1 tahun, tidak ada perbedaan yang mencolok terhadap kegiatan pendidikan keluarga yang ada di Kampung KB ketika 
dicanangkan karena hanya beberapa lintas sektor yang terlibat dalam menyukseskan pendidikan keluarga pada Kampung KB. Selain itu, pertemuan rutin POKJA (tingkat desa) Kampung KB satu kali sebulan dilaksanakan di Kantor Lurah yang dihadiri oleh seluruh Kader KB dengan materi pendampingan PUS yang hamil atau kegiatan TRIBINA. Sementara itu, pertemuan rutin POKJA Kampung KB dilaksanakan pada KB/KS Kelurahan, sedangkan sarasehan tingkat RT tidak pernah dilaksanakan.

Responden Ketua Kampung KB Bangau Putih melaksanakan perannya sebagai pengurus yang ditetapkan melalui SK Kelurahan dengan menyosialisasikan dan mendukung setiap program Kampung KB sebagai bentuk pendidikan keluarga. Responden Ketua Kampung KB Kubu Gadang melaksanakan perannya sebagai pengurus Kampung KB yang ditetapkan melalui SK Wali Kota dengan memberi dukungan dan mendampingi setiap kegiatan pendidikan keluarga yang dilaksanakan di Kampung KB dan selalu melengkapi data serta informasi tentang Kampung KB.

Responden Ketua Kampung KB Jorong Pondok melaksanakan perannya sebagai pengurus yang ditetapkan melalui SK Bupati dengan menyosialisasikan, memberi dukungan, dan mendampingi setiap kegiatan yang dilaksanakan di Kampung KB. Responden Ketua Kampung KB Payo Sejahtera melaksanakan perannya sebagai pengurus yang ditetapkan melalui SK Wali Kota dengan mengajak dan menjaga apa yang telah dilaksanakan selama Kampung KB berjalan.

Kegiatan-kegiatan pendidikan keluarga yang dilakukan pada setiap Kampung KB, yaitu kegiatan baca dengan adanya perpustakaan komunitas, kegiatan Kampung Wisata dengan konsep pemberdayaan masyarakat, kegiatan yang berhubungan dengan KKBPK, dan mengintegrasikan setiap program yang ada dengan kegiatan Kampung KB.

Kampung KB Bangau Putih dalam melaksanakan kegiatan pendidikan keluarga selalu mengadakan pertemuan rutin pengurus satu kali sebulan yang dihadiri oleh KaderKader terkait, UPTD dan lain-lain dengan topik perencanaan program selanjutnya dalam memajukan Kampung KB sebagai tempat pendidikan keluarga. Sementara itu, Kampung KB Kubu Gadang, Kampung KB Jorong Pondok, dan Kampung KB Payo Sejahtera mengadakan pertemuan rutin pengurus Kampung KB satu kali sebulan di Kampung KB yang dihadiri oleh tokoh masyarakat dan masyarakat dengan topik kegiatan yang akan dilakukan dan evaluasi kegiatan yang telah dilakukan. Selain itu, terdapat pula sarasehan Tingkat RW terkait kegiatan Kampung KB yang dilaksanakan satu kali sebulan di Rumah Ketua PLKB, Masjid, Gedung Serba Guna, dan Pos Ronda yang dihadiri oleh RT/RW, Kader-Kader, UPTD, Lurah dan tokoh masyarakat dengan topik kajian pelaksanaan kegiatan-kegiatan pendidikan keluarga yang dapat memajukan Kampung KB.

Responden Tokoh Agama di Kampung KB Bangau Putih melaksanakan perannya sebagai pengurus yang ditetapkan melalui SK Kelurahan dengan menjadi dai di Kampung KB. Responden Tokoh Agama di Kampung KB Kubu Gadang melaksanakan perannya sebagai pengurus yang ditetapkan melalui SK Wali Kota dengan menjadi ustaz di Kampung KB dan merekomendasikan KB kepada masyarakat. Responden Tokoh Agama di Kampung KB Jorong Pondok melaksanakan perannya sebagai pengurus yang ditetapkan melalui SK Bupati dengan merekomendasikan pula KB kepada masyarakat dan merekomendasikan kegiatan PIK-R berbasis Remaja Masjid. Sementara itu, responden Tokoh Agama di Kampung KB Payo Sejahtera melaksanakan perannya sebagai pengurus yang ditetapkan melalui SK Wali Kota dengan mengedukasi masyarakat tentang Kampung KB melalui kegiatan PIK-R berbasis Remaja Masjid, Posyandu Ibu-lbu dan Lansia serta Kader Lansia.

Responden Tokoh Masyarakat di Kampung KB Bangau Putih melaksanakan perannya sebagai pengurus yang ditetapkan melalui SK Kelurahan dengan mendukung programprogram yang ada di Kampung KB. Responden Tokoh Masyarakat di Kampung KB Kubu Gadang melaksanakan perannya sebagai pengurus yang ditetapkan melalui SK Wali Kota dengan menjadi Datuk di Kampung KB. Sementara itu, responden Tokoh Masyarakat di Kampung KB Jorong Pondok melaksanakan perannya sebagai pengurus yang ditetapkan melalui SK Bupati dengan mendorong dan mendukung setiap kegiatan yang ada di Kampung KB. Responden Tokoh Masyarakat di Kampung KB Payo Sejahtera melaksanakan perannya sebagai pengurus yang ditetapkan melalui SK Wali Kota dengan mendukung setiap kegiatan yang direncanakan dan dilaksanakan di Kampung KB. 
Responden Seksi Kampung KB Bangau Putih, Kampung KB Kubu Gadang, Kampung KB Jorong Pondok, dan Kampung KB Payo Sejahtera melaksanakan perannya sebagai pengurus Kampung KB yang ditetapkan melalui SK dari pihak berwenang dengan menjelaskan tentang Kampung KB kepada Masyarakat dan mendukung setiap kegiatan pendidikan keluarga pada Kampung KB seperti kegiatan PIK-R di masyarakat.

Responden Ketua PKK di Kampung KB Bangau Putih, Kampung KB Kubu Gadang, Kampung KB Jorong Pondok, dan Kampung KB Payo Sejahtera melaksanakan perannya sebagai pengurus dengan mendukung dan mendampingi setiap program yang ada di Kampung KB, melengkapi data serta informasi tentang Kampung KB, dan menjelaskan kepada seluruh masyarakat tentang pentingnya kegiatan pendidikan keluarga pada Kampung KB. Lebih lanjut, dalam pelaksanaan kegiatan pendidikan keluarga selalu diadakan pula pertemuan rutin pengurus Kampung KB satu kali sebulan di Balai Desa atau Kantor Desa yang dihadiri oleh Masyarakat dan Kader-Kader terkait dengan materi yang dibahas tentang pengembangan Kampung KB.

\section{Sarana dan Prasarana Kampung KB dalam Pendidikan Keluarga}

Hasil penelitian memperlihatkan bahwa fasilitas yang tersedia pada setiap Kampung KB dalam pelaksanaan pendidikan keluarga masih belum lengkap sehingga kinerja dalam pengembangan Kampung KB belum optimal. Sarana dan prasarana yang sudah tersedia di Kampung KB Bangau Putih adalah Mobil Penerangan dan Pelayanan KB yang beroperasi ketika ada pelayanan saja serta sarana terkait di mitra atau lintas sektor seperti media KIE Kesehatan. Sarana dan prasarana yang sudah ada di Kampung KB Kubu Gadang adalah Media KIE KKBPK (spanduk, nack drop, umbul-umbul, lembar balik, dan lain-lain), ruangan/gedung/aula termasuk meja, kursi, tenda, sound system, dokumentasi video dan foto, fasilitas pendukung lainnya serta sarana terkait di mitra/lintas sektor seperti media KIE Kesehatan.

Sementara itu, sejak Kampung KB Jorong Pondok terbentuk, belum terdapat sarana dan prasarana yang dapat digunakan dalam mendukung kegiatan pendidikan keluarga di Kampung KB, seperti Media KIE KKBPK (spanduk, back drop, umbul-umbul, lembar balik, dan lain-lain), ruangan/gedung/aula termasuk meja, kursi, tenda, sound system, dokumentasi video dan foto serta fasilitas pendukung lainnya serta sarana terkait di mitra/lintas sektor seperti media KIE Kesehatan. Sarana dan prasarana yang sudah dimiliki oleh Kampung KB Payo Sejahtera adalah infocus dan laptop untuk PIK Remaja, Media KIE KKBPK (spanduk, back drop, umbulumbul, lembar balik, dan lain-lain), Mobil Penerangan dan Pelayanan KB, ruangan/gedung/aula termasuk meja, kursi, tenda, sound system, dokumentasi video dan foto serta fasilitas pendukung lainnya serta sarana terkait di mitra/lintas sektor seperti media KIE Kesehatan.

\section{Pencapaian Indikator Program Kampung KB dalam Pelaksanaan Pendidikan Keluarga}

Hasil penelitian menunjukkan bahwa dalam praktiknya, kegiatan Monitoring Evaluasi (Monev), pencatatan, dan pelaporan setiap kegiatan oleh BKKBN dan OPD lainnya ini belum berjalan dengan optimal dan belum mampu memenuhi antusiasme masyarakat dalam pengembangan Kampung KB Bangau Putih, Kubu Gadang, Jorong Pondok, dan Payo Sejahtera sebagai tempat pendidikan keluarga. Fakta di lapangan menunjukkan bahwa BKKBN Provinsi melalui Bidang OPD KB melakukan pemantauan dan evaluasi pada kegiatan Kampung KB Bangau Putih secara tidak rutin dan tidak optimal. Selain itu, BKKBN Provinsi serta OPD Kab/Kota pernah melakukan kunjungan dan pembinaan terhadap Kampung $\mathrm{KB}$, akan tetapi masih minim dan tanpa diikuti dengan Monev dari BKKBN Provinsi secara terencana dan terprogram dengan jelas.

Selain itu, hasil analisis memperilhatkan bahwa Kampung KB hanya sekadar nawacita yang belum berusaha diwujudkan secara sungguhsungguh karena usaha yang dilakukan oleh BKKBN hanya pembekalan teori saja dan minimnya penganggaran dana (hanya untuk pencanangan saja) juga berpengaruh terhadap operasional Kampung KB. Eksistensi Kampung KB Bangau Putih masih ada karena terintegrasi dengan program PKBM (Pusat Kegiatan Belajar Masyarakat). Tidak jauh berbeda dengan Kampung KB Bangau Putih, BKKBN dan OPD terkait di Kampung KB Kubu Gadang diharapkan secara berkelanjutan melakukan Monev, pencatatan, dan pelaporan setiap kegiatan yang diadakan oleh Kampung KB. Namun dalam praktiknya, kegiatan Monev, pencatatan, dan pelaporan setiap kegiatan oleh BKKBN dan OPD lainnya ini belum berjalan dengan optimal dan belum mampu memenuhi antusiasme masyarakat dalam pengembangan Kampung KB di Kubu Gadang. 
Hasil penelitian menunjukkan bahwa BKKBN Provinsi telah melakukan pemantauan kegiatan Kampung KB sebanyak satu kali terhadap mekanisme pelaporan kegiatan Kampung KB Kubu Gadang. Sementara itu, OPD Kab/Kota melakukan evaluasi kegiatan Kampung KB sebanyak dua kali dalam setahun berupa rapat koordinasi. BKKBN Provinsi melalui Bidang OPD KB melakukan pemantauan dan evaluasi pada kegiatan Kampung KB walaupun tidak rutin dan hal ini sangat tidak optimal. Selain itu, BKKBN Provinsi serta OPD Kab/Kota tidak pernah melakukan pembinaan terhadap Kampung KB tetapi melakukan pelatihan meskipun masih minim dan seharusnya Monev dari BKKBN Provinsi harus terencana dan terpogram dengan jelas. Selain itu, Kampung KB masih sekadar nawacita karena terintegrasi dengan Kampung Wisata dan sejak awal pembentukan sampai sekarang belum ada kegiatan yang efektif dan kesungguhan dari OPD baik dalam dukungan dana maupun mekanisme operasional Kampung KB.

Sementara itu, BKKBN dan OPD terkait dalam melakukan Monev, pencatatan, dan pelaporan setiap kegiatan yang diadakan oleh Kampung KB Jorong Pondok juga masih belum optimal dan belum mampu memenuhi antusiasme masyarakat dalam pengembangan Kampung KB di Jorong Pondok. Temuan penelitian menunjukkan bahwa BKKBN Provinsi telah melakukan pemantauan kegiatan Kampung KB sebanyak satu kali terhadap mekanisme pelaporan kegiatan Kampung KB. Sementara itu, OPD Kab/Kota melakukan evaluasi kegiatan Kampung KB sebanyak tiga kali dalam setahun melalui rapat koordinasi. BKKBN Provinsi melalui Bidang OPD KB melakukan pemantauan dan evaluasi pada kegiatan Kampung KB secara tidak berkala sehingga tidak berjalan secara optimal.

Kegiatan Monev, pencatatan, dan pelaporan setiap kegiatan yang diadakan Kampung KB Payo Sejahtera oleh BKKBN dan OPD terkait sudah menunjukkan taraf keoptimalan yang lebih baik dari Kampung KB lainnya. Hal ini terlihat dari temuan penelitian yang menunjukkan bahwa BKKBN Provinsi telah melakukan pemantauan kegiatan Kampung KB sebanyak satu kali terhadap mekanisme pelaporan kegiatan Kampung KB serta melakukan pembinaan terhadap Toga dan Toma. Sementara itu, OPD Kab/Kota melakukan evaluasi kegiatan Kampung KB sebanyak dua kali dalam setahun melalui rapat koordinasi serta melakukan pembinaan terhadap Kader Kampung KB dan Ibu-lbu
Posyandu. BKKBN Provinsi melalui Bidang OPD KB melakukan pemantauan dan evaluasi pada kegiatan Kampung KB sebanyak tiga kali dalam setahun yang dilakukan oleh Bidang KB, Bidang KS, Dalduk, Bidang Adpin, dan PKB.

\section{Pengetahuan dan Partisipasi Pasangan Usia Subur (PUS) dalam Kegiatan dan Program Pendidikan Keluarga pada Kampung KB}

Kampung KB Bangau Putih dalam melaksanakan pendidikan keluarga dapat dilihat dari pengetahuan dan partisipasi PUS pada setiap program dan kegiatan (Tabel 1).

Penelitian ini melibatkan 50 PUS di Kampung KB Bangau Putih. Hasil analisis menunjukkan bahwa lebih dari sepertiga PUS hanya memiliki pengetahuan dan partisipasi terkategori sangat baik pada aspek keluarga berencana. Hal ini dapat disebabkan oleh kurangnya bimbingan dan arahan dari pemerintah dalam pelaksanaan pendidikan keluarga.

Tabel 1 Pengetahuan dan partisipasi PUS di Kampung KB Bangau Putih

\begin{tabular}{|c|c|c|c|}
\hline Dimensi & Kategori & $\mathrm{n}$ & $\%$ \\
\hline \multirow[t]{2}{*}{ Keluarga berencana } & Tidak baik & 31 & 62,0 \\
\hline & $\begin{array}{l}\text { Sangat } \\
\text { baik }\end{array}$ & 19 & 38,0 \\
\hline \multirow[t]{3}{*}{$\begin{array}{l}\text { Penyuluh keluarga } \\
\text { berencana }\end{array}$} & $\begin{array}{l}\text { Kurang } \\
\text { baik }\end{array}$ & 2 & 4,0 \\
\hline & baik & 18 & 36,0 \\
\hline & $\begin{array}{l}\text { Sangat } \\
\text { baik }\end{array}$ & 30 & 60,0 \\
\hline \multirow[t]{3}{*}{ KIE individu } & $\begin{array}{l}\text { Kurang } \\
\text { baik }\end{array}$ & 18 & 36,0 \\
\hline & baik & 24 & 48,0 \\
\hline & $\begin{array}{l}\text { Sangat } \\
\text { baik }\end{array}$ & 8 & 16,0 \\
\hline \multirow[t]{3}{*}{ KIE kelompok } & $\begin{array}{l}\text { Kurang } \\
\text { baik }\end{array}$ & 16 & 32,0 \\
\hline & baik & 26 & 52,0 \\
\hline & $\begin{array}{l}\text { Sangat } \\
\text { baik }\end{array}$ & 8 & 16,0 \\
\hline \multirow[t]{3}{*}{ Pembangunan keluarga } & $\begin{array}{l}\text { Kurang } \\
\text { baik }\end{array}$ & 6 & 12,0 \\
\hline & Baik & 38 & 76,0 \\
\hline & $\begin{array}{l}\text { Sangat } \\
\text { baik }\end{array}$ & 6 & 12,0 \\
\hline \multirow[t]{4}{*}{ Kegiatan pengurus KB } & Tidak baik & 7 & 14,0 \\
\hline & $\begin{array}{l}\text { Kurang } \\
\text { baik }\end{array}$ & 23 & 46,0 \\
\hline & Baik & 9 & 18,0 \\
\hline & $\begin{array}{l}\text { Sangat } \\
\text { baik }\end{array}$ & 11 & 22,0 \\
\hline
\end{tabular}


Tabel 2 Pengetahuan dan partisipasi PUS di Kampung KB Kubu Gadang

\begin{tabular}{|c|c|c|c|}
\hline Dimensi & Kategori & $\mathrm{n}$ & $\%$ \\
\hline \multirow[t]{4}{*}{ Keluarga berencana } & $\begin{array}{l}\text { Tidak } \\
\text { baik }\end{array}$ & 13 & 26,0 \\
\hline & $\begin{array}{l}\text { Kurang } \\
\text { baik }\end{array}$ & 2 & 4,0 \\
\hline & Baik & 4 & 8,0 \\
\hline & $\begin{array}{l}\text { Sangat } \\
\text { baik }\end{array}$ & 31 & 62,0 \\
\hline \multirow[t]{3}{*}{$\begin{array}{l}\text { Penyuluh keluarga } \\
\text { berencana }\end{array}$} & $\begin{array}{l}\text { Tidak } \\
\text { baik }\end{array}$ & 1 & 2,0 \\
\hline & Baik & 12 & 24,0 \\
\hline & $\begin{array}{l}\text { Sangat } \\
\text { baik }\end{array}$ & 37 & 74,0 \\
\hline \multirow[t]{4}{*}{ KIE individu } & $\begin{array}{l}\text { Tidak } \\
\text { baik }\end{array}$ & 14 & 28,0 \\
\hline & $\begin{array}{l}\text { Kurang } \\
\text { baik }\end{array}$ & 2 & 4,0 \\
\hline & Baik & 33 & 66,0 \\
\hline & $\begin{array}{l}\text { Sangat } \\
\text { baik }\end{array}$ & 1 & 2,0 \\
\hline \multirow[t]{4}{*}{ KIE kelompok } & $\begin{array}{l}\text { Tidak } \\
\text { baik }\end{array}$ & 6 & 12,0 \\
\hline & $\begin{array}{l}\text { Kurang } \\
\text { baik }\end{array}$ & 11 & 22,0 \\
\hline & Baik & 32 & 64,0 \\
\hline & $\begin{array}{l}\text { Sangat } \\
\text { baik }\end{array}$ & 1 & 2,0 \\
\hline \multirow[t]{3}{*}{ Pembangunan keluarga } & $\begin{array}{l}\text { Tidak } \\
\text { baik }\end{array}$ & 1 & 2,0 \\
\hline & $\begin{array}{l}\text { Kurang } \\
\text { baik }\end{array}$ & 8 & 16,0 \\
\hline & Baik & 41 & 82,0 \\
\hline \multirow[t]{4}{*}{ Kegiatan pengurus KB } & $\begin{array}{l}\text { Tidak } \\
\text { baik }\end{array}$ & 4 & 8,0 \\
\hline & $\begin{array}{l}\text { Kurang } \\
\text { baik }\end{array}$ & 16 & 32,0 \\
\hline & Baik & 19 & 38,0 \\
\hline & $\begin{array}{l}\text { Sangat } \\
\text { baik }\end{array}$ & 11 & 22,0 \\
\hline
\end{tabular}

Selanjutnya, sebanyak 60 persen PUS memiliki pengetahuan dan partisipasi terkategori sangat baik pada aspek penyuluh keluarga berencana yang mengindikasikan bahwa pengelola telah melakukan kegiatan-kegiatan pembinaan dalam menyukseskan pelaksanaan pendidikan keluarga. Hampir setengah PUS memiliki pengetahuan dan partisipasi terkategori baik pada aspek KIE individu. Sementara itu, pada aspek KIE kelompok lebih dari setengah PUS memiliki pengetahuan dan partisipasi terkategori baik. Hal ini menunjukkan bahwa dukungan sarana dan prasarana memiliki posisi urgen dalam menyukseskan pelaksanaan pendidikan keluarga.

Selain itu, mayoritas PUS memiliki pengetahuan dan partisipasi terkategori baik pada aspek pembangunan keluarga. Hal ini memperlihatkan bahwa PUS memiliki antusiasme dalam pelaksanaan setiap kegiatan pendidikan keluarga di Kampung KB. Sementara itu, pengetahuan dan partisipasi mayoritas PUS terkategori kurang baik pada aspek kegiatan pengurus KB karena kegiatan Monev, pencatatan, dan pelaporan yang dilakukan oleh BKKBN dan OPD lainnya masih belum optimal.

Kampung KB Kubu Gadang dalam melaksanakan pendidikan keluarga dapat dilihat dari pengetahuan dan partisipasi PUS pada setiap program dan kegiatan (Tabel 2).

Penelitian ini melibatkan 50 PUS di Kampung KB Kubu Gadang. Hasil penelitian memperlihatkan bahwa lebih dari setengah PUS memiliki pengetahuan dan partisipasi terkategori sangat baik pada aspek keluarga berencana. Hal ini dapat disebabkan oleh pengelola telah memfasilitasi setiap kegiatan pendidikan keluarga di Kampung KB. Selanjutnya, sebanyak 74 persen PUS memiliki pengetahuan dan partisipasi terkategori sangat baik pada aspek penyuluh keluarga berencana sebagai indikasi bahwa hasil kegiatan sosialisasi yang diikuti pengelola teraktualisasi dengan adanya kegiatan-kegiatan pembinaan dalam pelaksanaan pendidikan keluarga.

Lebih lanjut, PUS memiliki tingkat pengetahuan dan partisipasi terkategori baik (66\%) pada aspek KIE individu. Sedangkan, pada aspek KIE kelompok tingkat pengetahuan dan partisipasi yang dimiliki PUS sebesar 64 persen pada kategori baik. Hal ini memperlihatkan bahwa semakin optimal dukungan sarana dan prasarana, semakin baik kualitas pelaksanaan pendidikan keluarga di Kampung KB. Hasil kajian menunjukkan mayoritas PUS memiliki pengetahuan dan partisipasi terkategori baik pada aspek pembangunan keluarga sebagai bentuk antusiasme PUS terhadap pelaksanaan kegiatan pendidikan keluarga. Sementara itu, pengetahuan dan partisipasi PUS terkategori baik pada aspek kegiatan pengurus KB namun BKKBN dan OPD lainnya masih harus bekerja secara optimal dengan melakukan Monev, pencatatan, dan pelaporan yang rutin.

Kampung KB Jorong Pondok dalam melaksanakan pendidikan keluarga dapat dilihat dari pengetahuan dan partisipasi PUS pada setiap program dan kegiatan (Tabel 3). 
Tabel 3 Pengetahuan dan partisipasi PUS di

\begin{tabular}{|c|c|c|c|}
\hline \multicolumn{4}{|c|}{ Kampung KB Jorong Pondok } \\
\hline Dimensi & Kategori & $\mathrm{n}$ & $\%$ \\
\hline \multirow[t]{4}{*}{ Keluarga berencana } & $\begin{array}{l}\text { Tidak } \\
\text { baik }\end{array}$ & 7 & 14,0 \\
\hline & $\begin{array}{l}\text { Kurang } \\
\text { baik }\end{array}$ & 5 & 10,0 \\
\hline & Baik & 10 & 20,0 \\
\hline & $\begin{array}{l}\text { Sangat } \\
\text { baik }\end{array}$ & 28 & 56,0 \\
\hline \multirow[t]{3}{*}{$\begin{array}{l}\text { Penyuluh keluarga } \\
\text { berencana }\end{array}$} & $\begin{array}{l}\text { Kurang } \\
\text { baik }\end{array}$ & 1 & 2,0 \\
\hline & Baik & 23 & 46,0 \\
\hline & $\begin{array}{l}\text { Sangat } \\
\text { baik }\end{array}$ & 26 & 52,0 \\
\hline \multirow[t]{4}{*}{ KIE individu } & $\begin{array}{l}\text { Tidak } \\
\text { baik }\end{array}$ & 5 & 10,0 \\
\hline & $\begin{array}{l}\text { Kurang } \\
\text { baik }\end{array}$ & 17 & 34,0 \\
\hline & Baik & 22 & 44,0 \\
\hline & $\begin{array}{l}\text { Sangat } \\
\text { baik }\end{array}$ & 6 & 12,0 \\
\hline \multirow[t]{4}{*}{ KIE kelompok } & $\begin{array}{l}\text { Tidak } \\
\text { baik }\end{array}$ & 2 & 4,0 \\
\hline & $\begin{array}{l}\text { Kurang } \\
\text { baik }\end{array}$ & 20 & 40,0 \\
\hline & Baik & 25 & 50,0 \\
\hline & $\begin{array}{l}\text { Sangat } \\
\text { baik }\end{array}$ & 3 & 6,0 \\
\hline \multirow[t]{2}{*}{ Pembangunan keluarga } & $\begin{array}{l}\text { Kurang } \\
\text { baik }\end{array}$ & 9 & 18,0 \\
\hline & Baik & 41 & 82,0 \\
\hline \multirow[t]{4}{*}{ Kegiatan pengurus KB } & $\begin{array}{l}\text { Tidak } \\
\text { baik }\end{array}$ & 4 & 8,0 \\
\hline & $\begin{array}{l}\text { Kurang } \\
\text { baik }\end{array}$ & 28 & 56,0 \\
\hline & Baik & 11 & 22,0 \\
\hline & $\begin{array}{l}\text { Sangat } \\
\text { baik }\end{array}$ & 7 & 14,0 \\
\hline
\end{tabular}

Keterangan: $n$ = jumlah responden; $\%$ = persentase

Penelitian ini melibatkan 50 PUS di Kampung KB Jorong Pondok. Hasil kajian menunjukkan lebih dari setengah PUS memiliki pengetahuan dan partisipasi terkategori sangat baik pada aspek keluarga berencana. Hal ini dapat dipahami karena pengelola telah melakukan pembinaan kader dan mencari sektor KB untuk menyukseskan pelaksanaan pendidikan keluarga. Selanjutnya, sebanyak 54 persen PUS memiliki pengetahuan dan partisipasi terkategori sangat baik pada aspek penyuluh keluarga berencana sebagai hasil dari adanya kegiatan-kegiatan pembinaan dalam pelaksanaan pendidikan keluarga yang dilakukan oleh pengelola.

Lebih lanjut, hampir setengah (44\%) PUS memiliki pengetahuan dan partisipasi terkategori baik pada aspek KIE individu. Pada aspek KIE kelompok, setengah PUS memiliki pengetahuan dan partisipasi terkategori baik. Hal ini memperlihatkan pentingnya dukungan sarana dan prasarana dalam menyukseskan pelaksanaan pendidikan keluarga.

Selain itu, sebagian besar PUS memiliki pengetahuan dan partisipasi terkategori baik pada aspek pembangunan keluarga yang mengindikasikan bahwa PUS memiliki antusiasme dalam setiap kegiatan dan program pendidikan keluarga. Sementara itu, pengetahuan dan partisipasi lebih dari separuh PUS terkategori kurang baik pada aspek kegiatan pengurus KB karena belum optimalnya kegiatan Monev, pencatatan, dan pelaporan setiap kegiatan oleh BKKBN dan OPD lainnya.

Kampung KB Payo Sejahtera dalam melaksanakan pendidikan keluarga dapat dilihat dari pengetahuan dan partisipasi PUS pada setiap program dan kegiatan (Tabel 4). Penelitian ini melibatkan 50 PUS di Kampung KB Payo Sejahtera. Hasil analisis memperlihatkan hampir setengah PUS memiliki pengetahuan dan partisipasi terkategori sangat baik pada aspek keluarga berencana yang ditandai dengan pengelola telah memberikan sosialisasi dan fasilitasi pelaksanaan setiap kegiatan pendidikan keluarga. Selanjutnya, setengah PUS memiliki pengetahuan dan partisipasi terkategori sangat baik pada aspek penyuluh keluarga berencana yang mengindikasikan bahwa pengelola telah melakukan kegiatan-kegiatan pembinaan untuk menyukseskan pendidikan keluarga.

Lebih lanjut, PUS memiliki tingkat pengetahuan dan partisipasi terkategori baik (46\%) pada aspek KIE individu. Sementara itu, sebanyak 60 persen PUS memiliki pengetahuan dan partisipasi terkategori baik pada aspek KIE kelompok. Hal ini menunjukkan bahwa sudah ada dukungan sarana dan prasarana dalam pelaksanaan pendidikan keluarga meskipun masih belum maksimal. Selain itu, sebagian besar PUS pada aspek pembangunan keluarga memiliki pengetahuan dan partisipasi terkategori baik sebagai bentuk antusiasme PUS terhadap pelaksanaan kegiatan pendidikan keluarga.

Sementara itu, pengetahuan dan partisipasi mayoritas PUS terkategori kurang baik pada aspek kegiatan pengurus $\mathrm{KB}$. Hal ini mengharuskan BKKBN dan OPD lainnya bekerja dengan optimal untuk menjaga dan meningkatkan antusiasme masyarakat. 
Tabel 4 Pengetahuan dan partisipasi PUS di Kampung KB Payo Sejahtera

\begin{tabular}{|c|c|c|c|}
\hline Dimensi & Kategori & $\mathrm{n}$ & $\%$ \\
\hline \multirow[t]{4}{*}{ Keluarga berencana } & $\begin{array}{l}\text { Tidak } \\
\text { baik }\end{array}$ & 20 & 40,0 \\
\hline & $\begin{array}{l}\text { Kurang } \\
\text { baik }\end{array}$ & 2 & 4,0 \\
\hline & Baik & 6 & 12,0 \\
\hline & $\begin{array}{l}\text { Sangat } \\
\text { baik }\end{array}$ & 22 & 44,0 \\
\hline \multirow[t]{3}{*}{$\begin{array}{l}\text { Penyuluh keluarga } \\
\text { berencana }\end{array}$} & $\begin{array}{l}\text { Kurang } \\
\text { baik }\end{array}$ & 2 & 4,0 \\
\hline & Baik & 23 & 46,0 \\
\hline & $\begin{array}{l}\text { Sangat } \\
\text { baik }\end{array}$ & 25 & 50,0 \\
\hline \multirow[t]{4}{*}{ KIE individu } & $\begin{array}{l}\text { Tidak } \\
\text { baik }\end{array}$ & 4 & 8,0 \\
\hline & $\begin{array}{l}\text { Kurang } \\
\text { baik }\end{array}$ & 17 & 34,0 \\
\hline & Baik & 23 & 46,0 \\
\hline & $\begin{array}{l}\text { Sangat } \\
\text { baik }\end{array}$ & 6 & 12,0 \\
\hline \multirow[t]{3}{*}{ KIE kelompok } & $\begin{array}{l}\text { Kurang } \\
\text { baik }\end{array}$ & 16 & 32,0 \\
\hline & Baik & 30 & 60,0 \\
\hline & $\begin{array}{l}\text { Sangat } \\
\text { baik }\end{array}$ & 4 & 8,0 \\
\hline \multirow[t]{3}{*}{$\begin{array}{l}\text { Pembangunan } \\
\text { keluarga }\end{array}$} & $\begin{array}{l}\text { Kurang } \\
\text { baik }\end{array}$ & 7 & 14,0 \\
\hline & Baik & 38 & 76,0 \\
\hline & $\begin{array}{l}\text { Sangat } \\
\text { baik }\end{array}$ & 5 & 10,0 \\
\hline \multirow[t]{4}{*}{$\begin{array}{l}\text { Kegiatan pengurus } \\
\text { KB }\end{array}$} & $\begin{array}{l}\text { Tidak } \\
\text { baik }\end{array}$ & 2 & 4,0 \\
\hline & $\begin{array}{l}\text { Kurang } \\
\text { baik }\end{array}$ & 21 & 42,0 \\
\hline & Baik & 14 & 28,0 \\
\hline & $\begin{array}{l}\text { Sangat } \\
\text { baik }\end{array}$ & 13 & 26,0 \\
\hline
\end{tabular}

\section{PEMBAHASAN}

Hasil analisis menunjukkan adanya pelaksanaan pendidikan keluarga pada Kampung KB yang meliputi kegiatan keluarga berencana, PKB, KIE individu, KIE kelompok, pembangunan keluarga, dan kegiatan pengurus KB untuk mengatasi masalah kependudukan. Hasil ini mendukung penelitian-penelitian terdahulu yang juga memperlihatkan bahwa kegiatan Kampung KB dilakukan untuk mengatasi masalah kependudukan (Mardani et al., 2020; Sari et al., 2018). Tidak hanya itu, penelitian Karuniawati, Iswantiningsih, dan Mahmudah (2020) serta Yustini dan Lasmiana (2019) menunjukkan bahwa Kampung KB ada untuk mengatasi masalah KKBPK. Sementara itu, Raikhani et al. (2018) juga menemukan bahwa keberadaan Kampung KB memiliki kontribusi yang signifikan terhadap penguatan KKBPK. Saputra, Lukas, dan Rindantya (2019) menyatakan bahwa pelaksanaan pendidikan keluarga pada Kampung KB yang dicanangkan tahun 2016 dilakukan untuk menciptakan kesejahteraan dan ketahanan keluarga. Hal ini juga didukung oleh hasil penelitian Herawati et al. (2020) serta Wijayanti dan Berdame (2019) bahwa peningkatan ketahanan dan kesejahteraan keluarga bisa dilihat dari berbagi aspek sebagai cerminan dari implementasi 8 fungsi keluarga yang dipengaruhi oleh berbagai faktor. Widyanti, Hastuti, dan Alfiasari (2012) mengatakan bahwa berjalannya fungsi keluarga sangat dipengaruhi oleh faktor ekonomi termasuk dalam hal pemenuhan pendidikan.

Hasil penelitian memperlihatkan bahwa aspek pengelolaan Kampung KB, sarana dan prasarana, pencapaian indikator program serta pengetahuan dan partisipasi PUS saling memiliki keterkaitan dalam menyukseskan pendidikan keluarga untuk mengatasi masalah kependudukan. Hal ini mengindikasikan bahwa semakin bagus pengelolaan Kampung KB, adanya dukungan sarana dan prasarana yang memadai, terlaksananya kegiatan Monev, pencatatan, dan pelaporan setiap kegiatan oleh BKKBN dan OPD lainnya untuk mengetahui pencapaian indikator program serta pengetahuan dan partisipasi PUS yang dimiliki sangat baik maka akan mendukung pelaksanaan pendidikan keluarga untuk mengatasi masalah kependudukan. Kampung $\mathrm{KB}$ dengan dukungan yang bagus dari setiap aspek tentunya akan memiliki kualitas dalam pelaksanaan pendidikan keluarga untuk mengatasi masalah kependudukan. Wita (2019) menyatakan bahwa tanpa adanya dukungan dari beragam aspek yang saling terkait, maka pelaksanaan berbagai program dan kegiatan di Kampung KB tidak akan berjalan sesuai dengan yang diharapkan.

Hasil analisis menunjukkan bahwa belum ada langkah dan upaya strategis dari pemerintah dan stakeholder dalam pelaksanaan pendidikan keluarga pada Kampung KB untuk mengatasi masalah kependudukan sejak dicanangkan tahun 2016. Langkah dan upaya strategis dari pemerintah dan stakeholder dapat menentukan keberhasilan pelaksanaan pendidikan keluarga untuk mengatasi masalah kependudukan. Pemerintah dan stakeholder perlu memantau perkembangan dari pelaksanaan kegiatan pendidikan keluarga pada Kampung KB secara rutin pada tiap triwulan, semester, dan tahunan berdasarkan laporan yang diterima dari pengelola Kampung KB (BKKBN, 2016). 
Mardiyono (2017) menyatakan bahwa keberhasilan pelaksanaan pendidikan keluarga di Kampung KB untuk mengatasi masalah kependudukan ditentukan oleh komitmen yang kuat dari pemangku kebijakan; adanya integritas program KKBPK dan lintas sektor; optimalisasi fasilitas dan dukungan dari mitra atau stakeholder; semangat dan dedikasi setiap pengelola program KKBPK di lini lapangan; serta peran aktif masyarakat/keluarga. Dengan adanya komitmen dan sinergitas pemerintah dan stakeholder, maka Kampung KB akan semakin eksis dalam melaksanakan pendidikan keluarga untuk meningkatkan kesejahteraan dan ketahanan keluarga sebagai upaya mengatasi masalah KKBPK.

Hasil penelitian memperlihatkan bahwa beberapa aspek pengetahuan dan partisipasi PUS dalam pelaksanaan pendidikan keluarga didominasi kategori kurang baik dan tidak baik. Pengetahuan dan partisipasi PUS dapat memengaruhi pelaksanaan pendidikan keluarga untuk mengatasi masalah kependudukan. Hal ini mengindikasikan bahwa semakin baik pengetahuan dan partisipasi PUS maka akan semakin baik pelaksanaan pendidikan keluarga untuk mengatasi masalah kependudukan. PUS yang memiliki pengetahuan dan partisipasi yang baik tentunya akan memiliki kesadaran lebih tinggi untuk mengaplikasikan dan mengaktualisasikan pengetahuan yang dimilikinya. Endah dan Kholiq (2019) serta Sabilla dan Purnaningsih (2020) menyatakan bahwa di antara indikator keberhasilan Kampung KB dalam melaksanakan pendidikan keluarga untuk mengatasi masalah kependudukan adalah adanya pengetahuan dan partisipasi yang baik dari seluruh potensi Kampung KB. Hal ini menunjukkan bahwa semakin baik pengetahuan dan partisipasi PUS dalam pelaksanaan pendidikan keluarga, maka akan semakin baik Kampung KB dapat mengatasi masalah kependudukan.

\section{SIMPULAN DAN SARAN}

Kampung KB sebagai tempat pelaksanaan pendidikan keluarga belum menunjukkan posisi sentral untuk mengatasi masalah kependudukan. Sementara itu, secara keseluruhan PUS memiliki pengetahuan dan partisipasi yang didominasi oleh kategori sangat baik dan baik dalam pelaksanaan pendidikan keluarga pada Kampung KB untuk meminimalisir dan mengatasi masalah kependudukan. Selain itu, pengetahuan dan partisipasi PUS pada beberapa aspek, seperti
Kegiatan Pengurus KB di setiap Kampung KB belum mencapai kategori sangat baik. Penelitian ini terbatas dilaksanakan pada beberapa Kampung KB dan hanya melibatkan 50 PUS sehingga dipandang masih belum merepresentasikan pengetahuan dan partisipasi PUS secara komprehensif.

Peneliti berikutnya yang ingin melaksanakan penelitian dengan tema ini hendaknya memperhatikan komitmen dan sinergitas pemerintah, pengelola, masyarakat, dan stakeholder dalam melaksanakan pendidikan keluarga pada Kampung KB untuk mengatasi masalah kependudukan. Pemerintah/instansi/stakeholder terkait harus menjalankan amanah yang diemban dengan optimal untuk menyukseskan pelaksanaan pendidikan keluarga pada Kampung KB untuk mengatasi masalah kependudukan.

\section{DAFTAR PUSTAKA}

Aji, M. S., \& Yudianto, G. P. H. (2020). Pemberdayaan masyarakat "Kampung KB" ditinjau dari perspektif Ottawa Charter. Jurnal Promkes: The Indonesian Journal of Health Promotion and Health Education, 8(2), 206-218. doi:10.20473/jpk.v8.i2.2020.206-218.

Alpionita, Y., Arifin, J., \& Harahap, A. (2020). Persepsi masyarakat terhadap program Kampung KB dilihat dari aspek Bina Keluarga Balita (BKB) di Desa Nawin Kecamatan Haruai Kabupaten Tabalong. Jurnal Administrasi Publik dan Administrasi Bisnis, 3(1), 746-758.

Anggraeni, N., Afifuddin, \& Suyeno. (2020). Implementasi program kampung keluarga berencana dalam meningkatkan kualitas hidup masyarakat: Studi kasus Desa Sumberkarang Kabupaten Mojokerto. Jurnal Respon Publik, 14(1), 32-41.

Angisna, T. (2018). Evaluasi efektivitas pelatihan Kampung KB di perwakilan BKKBN Provinsi Jawa Timur. Jurnal PROMKES, 6(1), 93-104. doi:10.20473/jpk.v6.i1.2018.93-104.

Arikunto, S., \& Jabar, C. S. A. (2009). Evaluasi Program Pendidikan: Pedoman Teoritis Praktis Bagi Mahasiswa dan Praktisi Pendidikan. Jakarta, ID: Bumi Aksara.

Bachtiyar, N. A., \& Wibawani, S. (2018). Implementasi program kampung keluarga berencana di Dusun Ambeng-Ambeng Desa Ngingas Kecamatan Waru Kabupaten Sidoarjo. Dinamika 
Governance: Jurnal IImu Administrasi Negara, $\quad 7(1)$, 13-26. doi:10.33005/jdg.v7i1.1194.

[BKKBN] Badan Kependudukan dan Keluarga Berencana Nasional. (2016). Petunjuk Teknis Kampung KB. Jakarta, ID: Badan Kependudukan dan Keluarga Berencana Nasional.

[BKKBN] Badan Kependudukan dan Keluarga Berencana Nasional. (2017a). Pedoman Pengelolaan Kampung KB: Pedoman Bagi Pengelola Kampung KB di Lini Lapangan). Jakarta, ID: Badan Kependudukan dan Keluarga Berencana Nasional.

[BKKBN] Badan Kependudukan dan Keluarga Berencana Nasional. (2017b). Statistik Kampung KB. Jakarta, ID: Badan Kependudukan dan Keluarga Berencana Nasional.

[BPS] Badan Pusat Statistik. (2018). Provinsi Sumatra Barat dalam Angka 2018. Padang, ID: Badan Pusat Statistik.

Departemen Agama. (2008). Al-Hikmah; AlQuran dan Terjemahannya. Bandung, ID: Diponegoro.

Endah, K., \& Kholiq, A. W. (2019). Pelaksanaan program Kampung Keluarga Berencana oleh Dinas Keluarga Berencana, Pemberdayaan Perempuan dan Perlindungan Anak (KBP3A) dalam mewujudkan kehidupan masyarakat sejahtera: Studi Desa Babakan Kecamatan Pangandaran Kabupaten Pangandaran). Jurnal Moderat, 5(2), 101112. doi:10.25147/moderat.v5i2.2402.

Handayani, A., Najib, Ardini, S. N., \& Yulianti, P. D. (2020). The evaluation studies of Kampung KB in Central Java. JKKP: Jurnal Kesejahteraan Keluarga dan Pendidikan, 7(1), 63-73. doi:10.21009/JKKP.071.06.

Herawati, T., Pranaji, D. K., Pujihasvuty, R., \& Latifah, E. W. (2020). Faktor-faktor yang memengaruhi pelaksanaan fungsi keluarga di Indonesia. Jurnal IImu Keluarga dan Konsumen, 13(3), 213-227. doi:10.24156/jikk.2020.13.3.213.

HM, R., \& Indrawadi, J. (2019). Implementasi program Kampung KB dalam meningkatkan kesejahteraan masyarakat di Kelurahan Gunung Pangilun Kecamatan Padang Utara Kota Padang. Journal of Civic Education, 2(4), 295-301. doi:10.24036/jce.v2i4.233.

Istiadi, A., \& Rosdiana, W. (2012).
Implementasi program Kampung Keluarga Berencana: Studi pada kelompok sasaran keluarga dengan remaja di Dusun Waung Desa Sonoageng Kecamatan Prambon Kabupaten Nganjuk. Publika, 5(4), 1-8.

Karuniawati, B., Iswantiningsih, E., \& Mahmudah, S. (2020). Optimalisasi Kampung KB: Inovasi strategis pemberdayaan masyarakat di Dusun Gondang Kelurahan Donokerto Kecamatan Turi. Jurnal Pengabdian Masyarakat Karya Husada, 2(1), 10-17.

Kusumah, W., \& Dwitagama, D. (2011). Penelitian Tindakan Kelas. Jakarta, ID: PT Indeks.

Mardani, N. K. T., Winaya, I. K., \& Purnamaningsih, P. E. (2020). Evaluasi program Kampung Keluarga Berencana di Kota Denpasar. Jurnal IImu Administrasi Negara, 1(1), 1-8.

Mardiyono. (2017). Kampung KB sebagai upaya pemberdayaan masyarakat/ keluarga di Jawa Timur: Studi di Kota Malang dan Kabupaten Bondowoso. Jurnal Cakrawala, 11(2), 129-136. doi:10.32781/cakrawala.v11i2.13.

Mardiyono. (2017). Pemberdayaan keluarga melalui Kampung KB dalam upaya peningkatan program KKBPK dan terkait di Jawa Timur. Jurnal Keluarga Berencana, 2(1), 1-10.

Miles, M. B., Huberman, A. M., \& Saldana, J. (2014). Qualitative Data Analysis: A Methods Sourcebook (3rd ed.). United States, US: Sage Publications.

Normajatun, Malawat, S. H., \& Fibriyanita, F. (2018). Implementasi kebijakan program Kampung Keluarga Berencana - Kampung Baiman (KKB-KB) di Kota Banjarmasin. AS-SIYASAH: Jurnal IImu Sosial dan IImu Politik, 3(2), 47-50. doi:10.31602/as.v3i2.2084.

Nurjannah, S. N., \& Susanti, E. (2018). Implementasi program Kampung Keluarga Berencana (KB) di Kabupaten Kuningan Tahun 2018: Studi kuantitatif dan kualitatif. Jurnal IImu Kesehatan Bhakti Husada: Health Sciences Journal, 9(2), 27-33. doi:10.34305/jikbh.v9i2.64.

Prasetyo, J. A., \& Anggaunitakiranantika. (2020). Partisipasi masyarakat dalam pelaksanaan program keluarga sejahtera di Kampung KB. Sosietas Jurnal Pendidikan Sosiologi, 10(2), 834-840. doi:10.17509/sosietas.v10i2.30100. 
Pratiwi, A. I. (2019). Faktor-faktor yang berhubungan dengan keikutsertaan Pasangan Usia Subur (PUS) dengan penggunaan alat kontrasepsi di Desa Alamendah Kecamatan Rancabali Kabupaten Bandung. Jurnal Kebidanan, 8(1), 1-11. doi:10.47560/keb.v8i1.130.

Rahmeina, F. R. (2018). Koordinasi dalam program Kampung KB di Kota Pekanbaru. JOM FISIP, 5(1), 1-12.

Raikhani, A., Yunas, N. S., Ratnasari, L., \& Hariastuti, I. (2018). Analisa kontribusi program Kampung KB dalam upaya peningkatan program KKBPK di Kab. Jombang, Provinsi Jawa Timur. Jurnal IImiah Kebidanan (Scientific Journal of Midwifery), 4(2), 101-113. doi:10.33023/jikeb.v4i2.188.

Regina, Rusli, B., \& Candradewini. (2020). Koordinasi pengembangan program Kampung Keluarga Berencana di Kabupaten Bangka Barat. JAKPP (Jurnal Analisis Kebijakan dan Pelayanan Publik), 6(1), 65-85. doi:10.31947/jakpp.v6i1.8489.

Restiyani, N. L. N., \& Yasa, I. G. W. M. (2019). Efektivitas program Kampung Keluarga Berencana (KB) dan dampaknya terhadap kesejahteraan keluarga miskin di Kota Denpasar. E-Jurnal Ekonomi dan Bisnis Universitas Udayanaan, 8(7), 711-740. doi:10.24843/eeb.2019.v08.i07.p03.

Rianto, F., Nengsih, N. S., \& Setyadiharja, R. (2019). Evaluasi program Kampung Keluarga Berencana di Kota Tanjungpinang. Jurnal Dimensi, 8(2), 286306. doi:10.33373/dms.v8i2.2158.

Roswati. (2008). Evaluasi program/proyek (Pengertian, fungsi, jenis, dan format usulan). Jurnal Pendidikan Penabur, 7(11), 64-71.

Sabilla, A.-N. V., \& Purnaningsih, N. (2020). Partisipasi masyarakat dalam program Kampung Keluarga Berencana (KB): Studi kasus di Desa Kapas, Kecamatan Kunjang, Kabupaten Kediri, Jawa Timur. Jurnal Sains Komunikasi dan Pengembangan Masyarakat (JSKPM), 4(5), 713-729. doi:10.29244/jskpm.v4i5.569.

Saputra, Y. W., Lukas, A, T., \& Rindantya, R. S. (2019). Implementasi program Kampung Keluarga Berencana (KB) di Kota Samarinda. Jual Georafflesia, 4(2), 186200. doi:10.32663/georaf.v4i2.975.

Sari, L. R., Raikhani, A., Yunas, N. S., \&
Hariastuti, I. (2018). Analisis faktor yang mempengaruhi keberhasilan program Kampung KB di Kabupaten Jombang. Seminar Nasional Sumber Daya Lokal, 127-136. Madura, ID: UIM Press. doi:10.32682/jpekbm.v2i2.999.

Setiawati, E. (2017). Persepsi masyarakat terhadap program Kampung Keluarga Berencana di Kelurahan Pantoloan Boya Kecamatan Tawaeli. GeoTadulako, 5(1), $1-15$.

Sugiyono. (2013). Metode Penelitian Kuantitatif, Kualitatif, dan R\&D. Bandung, ID: Alfabeta.

Syahnur, S., Diantimala, Y., \& Ilham, R. (2019). Identifikasi kegiatan program Kampung Keluarga Berencana di Kabupaten Aceh Tengah. JPPUMA; Jurnal IImu Pemerintahan dan Sosial Politik Universitas Medan Area, 7(1), 71-80. doi:10.31289/jppuma.v7i1.2167.

Widodo, M. N., \& Anam, M. K. (2019). Kampung keluarga berencana dalam peningkatan efektivitas program keluarga berencana di wilayah Cilenggang. Prosiding Seminar Nasional Pengabdian Masyarakat LPPM UMJ, 1-4. Jakarta, ID: LPPM UMJ.

Widyanti, L., Hastuti, D., \& Alfiasari. (2012). Fungsi keluarga dan gejala stres remaja dengan latar belakang pendidikan prasekolah berbeda. Jurnal IImu Keluarga dan Konsumen, 5(1), 38-47. doi:10.24156/jikk.2012.5.1.38.

Wijayanti, U. T., \& Berdame, D. Y. (2019). Implementasi delapan fungsi keluarga di Provinsi Jawa Tengah. Jurnal Komunikasi, 11(1), 15-29. doi:10.24912/jk.v10i1.2475.

Wita, I. M. (2019). Implemantation of Kampung KB in increasing community self-help at Kampung KB. Jurnal Pendididkan Luar Sekolah, 7(2), 163-168. doi:10.24036/spektrumpls.v2i2.10323.

Wiwiek, E., \& Utami, S. (2020). Analisis tingkat partisipasi peserta keluarga berencana di Kampung KB Kelurahan Handil Bakti Kecamatan Palaran Kota Samarinda. Jurnal Keperawatan Dirgahayu, 2(1), 912.

Wulandari, T. (2008). Persepsi dan partisipasi masyarakat terhadap program keluarga berencana (Penelitian di Desa Panggunghajo, Kec. Sewon, Kab. Bantul). Jurnal Dimensia, 2(1), 18. doi:10.21831/dimensia.v2i1.3399. 
Yunas, N. S., \& Nailufar, F. D. (2019). Collaborative governance melalui program Kampung $\mathrm{Kb}$ di Kabupaten Jombang. CosmoGov: Jurnal IImu Pemerintahan, 5(2), 162-173. doi:10.24198/cosmogov.v5i2.21814.

Yustini, T., \& Lasmiana, L. (2019). Pemanfaatan KUR, pembentukan Koplay, penggunaan saluran distribusi daring (online): Solusi peningkatan usaha
Kampung KB Layang-Layang Kota Palembang. Mbia, 18(2), 100-115. doi:10.33557/mbia.v18i2.541.

Zuhriyah, A., Indarjo, S., \& Raharjo, B. B. (2017). Kampung Keluarga Berencana dalam peningkatan efektivitas program keluarga berencana. HIGEIA (Journal of Public Health Research and Development), 1(4), 1-13. 